\title{
CLINICOPATHOLOGIC REVIEW OF EXTRAPELVIC ENDOMETRIOSIS
}

\author{
Seong Eui Lee, MD, Ju Eun Jeong, MD, Jong Kil Joo, MD, Kyu-Sup Lee, MD \\ Department of Obstetrics and Gynecology, Pusan National University School of Medicine, Busan, Korea
}

\section{Objective}

To evaluate the clinicopathologic features of extrapelvic endometriosis in order to help diagnosis and treatment.

Methods

Thirty patients with extrapelvic endometriosis were surgically diagnosed at Pusan National University Hospital from January 1998 to December 2010. We retrospectively reviewed the medical records such as age, symptoms, preoperative diagnosis, past surgical history.

\section{Results}

There were 30 patients who were diagnosed extrapelvic endometriosis surgically with a mean age of 38 years. The main symptom was palpable mass with pain, noncyclic $(33 \%, n=9)$, or cyclic $(67 \%, n=21)$. Fifteen endometriomas were found in the previous scar of cesarean section and laparoscopic surgery. Three endometriomas were noted in episiotomy site and ten were in cervix. Inguinal and vaginal endometriosis, one case was investigated, respectively.

\section{Conclusion}

Diagnosis of extrapelvic endometriosis is difficult to diagnose because of its rarity and diversity of symptoms. Thus, It must be kept in mind as one of the differential diagnosis to treat patients with pain or palpable mass during menstrual cycle in or around surgical scars, even if vaginal spotting or abnormal pap test. Radical local excision help to treat and prevent recurrence of extrapelvic endometriosis.

Keywords: Extrapelvic emdometriosis; Symptom; Diagnosis; Treatment

자궁내막증이란 여성호르몬의 자극에 반응하는 자궁내막선과 기질 로 구성된 자궁내막조직이 자궁 외의 장소에서 증식하는 질환으로 주 로 월경통, 골반통, 성교통 및 불임과 같은 다양한 증상을 나타내며, 난 소, 자궁인대, 직장, 질 중격 및 복막 등에 호발하는 양성 부인과 질환 으로 그 이환율은 $10 \%$ 로 보고되고 있다. 그러나 드물게 배꼽, 충수돌 기, 질, 방광, 탈장낭, 폐, 신장, 사지과 개복술 후, 특히 제왕절개술 후 피부 반흔 부위, 질식분만 후 회음 절개부위 등, 비장을 제 골반 외에 서도 발생하는 것으로 보고되고 있으며, 이는 전체 자궁내막증 환자의 $10 \%$ 에서 보고되고 있다[1].

골반강외 자궁내막증은 그 빈도가 드물며, 발생 장소에 따라 다양한 임상 증상을 나타내므로 임상의의 주의가 필요하다. 이에 저자들은 부 산대학병원에서 조직학적으로 진단된 30예의 골반강외 자궁내막증에 대한 분석을 통해 골반강외 자궁내막증의 임상 양상에 대해 알아보고 자 한다.

\section{연구대상 및 방법}

1998년 1월부터 2009년 12월까지 부산대학교병원 산부인과에서

Received: 2011. 5.15. Revised: 2011. 7.14. Accepted: 2011. 8.22.

Corresponding author: Kyu-Sup Lee, MD

Department of Obstetrics and Gynecology, Pusan National

University School of Medicine, 49 Busandaehak-ro, Yangsan

626-815, Korea

Tel: +82-51-240-7287 Fax: +82-51-248-2384

E-mail: kuslee@pusan.ac.kr

This is an Open Access article distributed under the terms of the Creative Commons Attribution Non-Commercial License (http://creativecommons.org/licenses/ by-nc/3.0/) which permits unrestricted non-commercial use, distribution, and reproduction in any medium, provided the original work is properly cited.

Copyright $\odot$ 2012. Korean Society of Obstetrics and Gynecology 
자궁내막증으로 진단받은 1,450 명의 환자 중 골반강외 자궁내막증으 로 진단된 30명의 환자를 대상으로 하였다. 이들 환자는 모두 부산대 학교병원 산부인과에서 수술 후 조직학적으로 확진된 예를 대상으로 하였으며, 환자들의 의무기록에 대한 후향적 분석을 바탕으로 조사하 였다. 조사 항목으로는 환자의 나이, 월경력, 임신 및 출산력, 발생 부 위 및 증상, 과거 수술력, 수술 후 조직의 크기 및 최종 진단 등에 중점 을 두어 분석하였다. 이를 바탕으로 골반강외 자궁내막증의 발생 부위 에 따른 빈도 및 임상 양상의 특징을 비교, 연구하였으며 증례들에 대 한 단순한 빈도 분석으로 다른 통계처리는 수행하지 않았다.

\section{결 과}

조사기간 중 부산대학병원에서 수술 및 조직검사를 통해 자궁내막증 으로 진단된 전체 환자수는 1,450 명이었으며, 이 중 골반강외 자궁내 막증으로 진단된 환자는 30 명(2.01\%)이었다. 대상 환자들은 모두 가임 기 여성으로 평균 연령은 38세(범위, 26-50세)였다. 발생 부위별로는 이전 제왕절개술 및 복강경수술 반흔부에 발생한 예가 15 건, 질식분만 후 회음절개 부위에 나타난 예가 3 건, 자궁경부에 발생한 예가 10 건으 로 나타났으며, 서혜부 자궁내막증과 질내 자궁내막증도 각각 1 예씩 조사되었다.

대부분의 환자는 골반강외 자궁내막증 발생 부위의 통증을 동반하는
종괴를 주 증상으로 병원에 방문하였으며, 이 중 생리 주기와 연관된 주기적인 통증을 호소하는 경우는 21예(67\%)였다. 수술 전 진단을 위 해 영상 자료를 사용한 경우는 수술 후 우연히 진단된 자궁경부 자궁내 막증 10예를 제외한 나머지 20예 중 9예에서 자기공명영상(magnetic resonance imaging, MRI) 자료를 수술 전 진단 목적으로 사용하였으며, $\mathrm{MR} \mid$ 를 찍은 환자 중 6 명만이 수술 전 자궁내막증으로 추정 진단되어 수술을 받았다.

제왕절개술 후 수술반흔 부위에 자궁내막증이 발병한 경우는 14예 (47\%)였으며, 이 중 주기적인 반흔 부위 종괴 형성을 호소한 경우가 11 예(79\%)였다. 증상의 발현은 평균적으로 마지막으로 시행한 제왕절 개술 후 3.8년에 발생하였으며, 수술로 절제된 종괴의 평균 크기는 2.7 $\mathrm{cm}$ 였다(Table 1). 회음절개 부위의 자궁내막증은 3 예(10\%)에서 확인 되었으며, 이 중 생리 기관과 연관된 회음절개 부위 압통성 종괴를 주 소로 하는 경우는 2예(67\%)였다. 종괴의 크기는 평균 $2.7 \mathrm{~cm}$ 였으며, 증상의 발현은 평균적으로 마지막으로 분만 후 9.3년에 발생하였다 (Table 1). 그 외 질식 자궁절제술 후 질 벽에 발생한 예, 복강경수술 후 투관침(trocar) 자리에 발생한 예, 서혜부에 발생한 예가 각각 1예씩 관 찰되었다(Table 2).

자궁절제술 후 질벽에 발생한 환자의 경우 발생 2년 전 자궁근종으 로 질식 자궁절제술을 시행 받은 후 주기적인 통증을 동반한 $3 \mathrm{~cm}$ 크 기의 종괴를 주소로 방문하여 종괴에 대한 절제술 후에 자궁내막증으 로 확진되었으며, 복강경 투관침 부위에 발생한 경우는 내원 6 년 전 복

Table 1. Clinical characteristics of patients

\begin{tabular}{|c|c|c|c|c|}
\hline Age (yr) & Chief complaints & Cyclic pain & Mass size $(\mathrm{cm})$ & Interval from previous procedure (yr) \\
\hline \multicolumn{5}{|c|}{ Cesarean section scar endometriosis } \\
\hline 26 & Painful palpable mass & + & 3.8 & 1 \\
\hline 28 & Painful palpable mass & + & 1.3 & 4 \\
\hline 28 & Painful palpable mass & + & 2 & 2 \\
\hline 31 & Painful palpable mass & + & 2.4 & 3 \\
\hline 32 & Painful palpable mass & - & 2 & - \\
\hline 33 & Painful palpable mass & + & 2.5 & 3 \\
\hline 33 & Painful palpable mass & + & 2 & 3 \\
\hline 33 & Painful palpable mass & - & 0.7 & 6 \\
\hline 33 & Painful palpable mass & - & 2.8 & 6 \\
\hline 35 & Painful palpable mass & + & 5 & 5 \\
\hline 36 & Painful palpable mass & + & 5 & 5 \\
\hline 39 & Painful palpable mass & + & 3.2 & 6 \\
\hline 40 & Painful palpable mass & + & 2 & 4 \\
\hline 46 & Painful palpable mass & + & 3 & 2 \\
\hline \multicolumn{5}{|c|}{ Episiotomy scar endometriosis } \\
\hline 32 & Painful palpable mass & + & 3.2 & 4 \\
\hline 32 & Painful palpable mass & + & 2.7 & 8 \\
\hline 40 & Dyspareuria, postcoital spotting & - & 2.3 & 16 \\
\hline
\end{tabular}




\section{KOREAN JOURNAL OF OBSTETRICS \& GYNECOLOGY}

Seong Eui Lee, et al. Clinicopathologic review of extrapelvic endometriosis

Table 2. Clinical characteristics of patients

\begin{tabular}{|c|c|c|c|c|}
\hline Age (yr) & Remarkable past history & Chief complaints & Cyclic pain & Interval from previous procedure \\
\hline \multicolumn{5}{|c|}{ Cervix endometriosis } \\
\hline 33 & $\mathrm{C} / \mathrm{S}$ & Vaginal discharge & - & $6 \mathrm{yr}$ \\
\hline 39 & - & Dysmenorrhea & + & - \\
\hline 41 & Vaginal delivery & Dysmenorrhea & + & - \\
\hline 42 & - & Dysmenorrhea & - & - \\
\hline 42 & Vaginal delivery & Painful palpable mass & + & $7 \mathrm{yr}$ \\
\hline 43 & Conization (CIS) & - & - & $3 \mathrm{mo}$ \\
\hline 43 & $\mathrm{C} / \mathrm{S}$ & Painful palpable mass & - & $3 \mathrm{yr}$ \\
\hline 46 & - & Dysmenorrhea & + & - \\
\hline 46 & - & Dysmenorrhea & + & - \\
\hline 50 & Adenocarcinoma of cervix & - & - & - \\
\hline \multicolumn{5}{|c|}{ Vaginal wall } \\
\hline 41 & TVH (myoma) & Painful palpable mass & + & $2 \mathrm{yr}$ \\
\hline \multicolumn{5}{|c|}{ Laparoscopy port site } \\
\hline 44 & Laparoscopic myomectomy & Painful palpable mass & + & $6 \mathrm{yr}$ \\
\hline \multicolumn{5}{|c|}{ Inguinal lesion } \\
\hline 45 & - & Painless palpable mass & - & - \\
\hline
\end{tabular}

C/S, cesarean section; CIS, carcinoma in situ; TVH, total vaginal hysterectomy.

Table 3. Clinical characteristics of cervical endometriosis

\begin{tabular}{|llc|}
\hline Characteristics & Clinical problem & Frequency \\
\hline Abnormal Pap smear & AGUS & 1 \\
& HSIL & 1 \\
Cervical polyp & Class V & 1 \\
& Cervical polyp & 1 \\
Asymtomatic & Endometrial polyp & 1 \\
& Leiomyoma & 2 \\
& Endometrial hyperplasia & 1 \\
Total & Adenomyosis & 2 \\
\hline
\end{tabular}

AGUS, atypical glandular cells of undetermined significance; HSIL, high-grade squamous intraepithelial lesion.

Table 4. Previous diagnosed pelvic endometirosis

\begin{tabular}{|lllc|}
\hline & Present & Absent & Unknown \\
\hline Previous diagnosed pelvic endometirosis & $9(30 \%)$ & $8(27 \%)$ & $13(43 \%)$ \\
\hline
\end{tabular}

강경하 자궁근종절제술 시행받은 기왕력의 40 대 환자로 우측 보조 투 관침 부위에 주기성 통증을 동반한 $4 \mathrm{~cm}$ 크기의 종괴를 주소로 방문하 여 절제술 시행 후 자궁내막증으로 확진되었다. 서혜부에 발생한 경우 는 이전에 수술 기왕력이 없는 40대 여성에서 우측 샅고랑 인대(inguinal ligament)에 2-3 cm 크기의 무통성 종괴의 형태로 관찰되어 절제 후 자궁내막증으로 진단된 예였다.
자궁경부에 발생한 경우는 10 예(33\%)였으며, 이 중 특별한 증상 없 이 정기 산부인과 검진 시 자궁경부세포검사 이상으로 실시한 조직검 사에서 확인된 경우가 3 예(30\%), 신체검사상 자궁경부 용종이 관찰되 어 실시한 조직검사상 발견된 것이 2예(20\%)가 있었다. 또한 특별한 증상 없이 다른 산부인과 질환으로 수술 후 발견된 경우가 5 예(50\%)였 다(Table 3). 


\title{
KOREAN JOURNAL OF OBSTETRICS \& GYNECOLOGY
}

\author{
KJOG Vol. 55, No. 2, 2012
}

골반강외 자궁내막증 진단 당시나 과거력상 골반강내 자궁내막증으 로 진단된 경우는 9 예(30\%), 수술 기왕력은 있으나 조직학적으로 확진 되지 않은 경우는 8예(27\%), 이전 수술력이 없고, 골반강외 자궁내막증 수술 당시 골반수술을 동시에 시행치 않아 골반강내 자궁내막증의 유 무를 알 수 없었던 경우도 13예(43\%)가 있었다(Table 4).

\section{고 찰}

지궁내막증은 자궁내막의 선과 기질이 자궁강내가 아닌 다른 장소에 위치하는 질환으로, 에스트로겐 영향하에 증식하면서 다양한 임상 증 상을 보이는 질환이다. 자궁내막증은 가장 흔한 부인과 질환 중의 하나 로 Rokitansky에 의해 1860년에 처음으로 보고되었다[2]. 자궁내막증 이 호발하는 장소는 주로 난소, 난관, 자궁의 인대, 직장 질 중격, 자궁 의 표면, 골반복막 등 골반내 조직이다. 그 외에 직장, 대장, 충수돌기, 소장, 제부, 대망, 간, 담낭, 췌장, 탈장낭, 서혜부, 개복술반흔, 폐, 흉강, 횡격막, 중추신경계, 횡문근, 말초신경계 등에 생길 수 있다. 비장에서 는 보고된 바가 없는데 이는 다른 장기들과는 달리 비장 자체에서 면역 기전을 통해 자궁내막세포를 청소하는 것으로 추측되고 있다. 기계적 자궁내막 조직의 전이로 이소성 착상 자궁내막에 의해 자궁내막증이 발생하는 자궁내막 조직의 이식설(implantation or reflux theory)은 제왕 절개술 후 수술반흔이나 자연분만 후 회음절개 부위에서 자궁내막증이 발생하는 것을 설명해준다[3].

일반적으로 골반강내 자궁내막증의 경우 대표적인 증상으로 월경통, 성교통, 불임증 등이 있다. 그러나 골반강외 자궁내막증의 경우 그 임 상 양상은 발생 부위에 따라 매우 다양하여, 위장관에 발생했을 경우 복통, 출혈, 장폐색, 장중첩증 등이 있을 수 있고, 요관계의 자궁내막증 은 요관 폐쇄, 측복통, 오한, 배뇨 곤란, 혈뇨 등이 있을 수 있으며, 폐를 침범한 경우에는 기흉, 혈흉, 월경 시 객혈 등이 나타날 수 있다. 제대 부위 주변에 주기적인 통증이 있거나, 종괴가 촉지되면 제부의 자궁내 막증을 생각할 수 있다. 그리고 수술반흔 자궁내막증은 주로 압통을 동 반하는 결절로 나타나며, 환자의 반수 정도에서 월경과 관련된 주기적 인 동통을 동반한 종괴가 나타난다[4]. 본 연구 결과 역시 제왕절개 반 흔 부위의 주기적 압통을 호소하는 예가 $79 \%$ 였으며, 회음절개 부위의 주기적 압통을 호소하는 경우는 3 예에서 관찰되었다.

수술반흔 자궁내막증은 복벽 절개부, 복강경 반흔부, 회음 절개부, 바 르톨린선 제거 부위에 발생하며, 서혜부 탈장수술이나 양수검사 이후에 도 보고된 바 있다[5,6]. 본 연구 결과에서도 골반강외 자궁내막증 중 수 술반흔 자궁내막증이 $63 \%$ 로 가장 많았으며, 이 중 복벽절개부, 본 연구 에서는 제왕절개반흔부가 $84 \%$ 로 가장 많은 빈도를 보였다. 이 중 수술 반흔 부위나 회음절개 부위 등에 발생하는 자궁내막증의 경우는 월경 시 심해지는 통증과 종괴 등으로 나타날 수 있다. 감별해야 할 것으로는 복벽 반흔에서 보여지는 봉합 육아종, 암종, 농양, 탈장이나 피지낭 등이 있다. 복벽에 발생하는 종양의 병력 청취 시 생리통 여부를 물어보는 것 은 자궁내막증 진단에 도움을 준다. 수술반흔 자궁내막증과 골반내 자
궁내막증이 동반되는 경우는 $24 \%$ 까지 보고된 바 있으나, 동반된 골반 강내 자궁내막증 병변이 없다는 보고도 있다. 본 연구에서는 $30 \%$ 의 환 자에서 골반강내 자궁내막증의 과거력을 확인할 수 있었다(Table 4).

골반강외 자궁내막증을 진단하는 방법으로는 복부초음파, 복부컴퓨 터단층촬영, 미세 바늘에 의한 조직흡입술이 등이 있다. 회음부에 발 생한 자궁내막증의 경우 항문 초음파가 괄약근 침범 유무 정도의 파악 을 위해 유용하게 사용된다[7,8]. MRl는 고해상도의 영상으로 작은 병 변과 자궁 내막종내의 출혈을 감별할 수 있는 장점이 있고 computed tomography (CT)보다 근육과 피하지방층 사이의 종괴를 진단하는데 우수하여 최근 각광받고 있다. MRI상의 골반강외 자궁내막종의 경우 골반 내 자궁내막종과 유사하게 T2 영상에서는 아급성 출혈에 합당한 고신호 강도를 보이고, $\mathrm{T} 1$ 영상에서는 세포외 methemoglobin에 의해 밝은 신호를 보인다[9]. 본 연구에서 MRI를 수술 전 진단방법으로 사용 한 경우는 9 예(30\%)였으며, 이 중 6예(67\%)에서 자궁내막증으로 진단 되어 MRI가 수술 전 진단에 도움이 됨을 확인할 수 있었다. 그러나 3예 에서는 전형적인 아급성 출혈의 고신호 강도가 보이지 않아 영상의학 적으로 진단이 어려웠으며, 이 경우 영상의학과 전문의에게 종괴의 부 위와 주기적 압통과 같은 정확한 임상 정보 제공이 진단율을 높이는 데 도움을 준다.

산과적 혹은 수술적 손상 후 자궁내막증이 발생하는 시기는 Dragoumis 등[10]은 수술 후 평균 4.5년, Blanco 등[4]은 1.9년 후라고 보고하였으 며 우리나라의 경우 Kang 등[11]의 보고에 의하면 6 예의 증례에서 증 상발현까지 평균 64.3개월이라는 보고가 있다. 저자들의 경우 22예에 서 초기 병인 제거술 이후 반흔 부위 자궁내막증수술을 받기까지의 평 균 기간은 4.4년이었다.

수술 후 반흔에 발생하는 골반강외 자궁내막증의 경우 그 발생 부위 가 이전 수술 부위와 떨어져 있는 경우가 많고, 수술 이후 2년 이상의 시간이 경과한 후에 대부분 발생하므로, 환자들은 산부인과를 찾기보 다는 일반외과를 먼저 방문한다. 따라서 진단은 더 느려지게 되는 경우 가 많다. 병변의 크기는 대개 3-5 cm 정도이며 $10 \mathrm{~cm}$ 이 넘는 경우도 있다. 본 연구에서 종괴를 형성한 경우 그 평균 크기는 $2.7 \mathrm{~cm}$ 정도로 문헌과 비슷한 양상을 보였다. Seydel 등[12]은 수술 전 정확한 진단이 내려지는 경우는 주기적인 동통을 호소하는 종괴가 나타난 $33 \%$ 에 불 과하다고 하였으며, Blanco등[4]도 수술 전 진단율을 20-50\%로 보고 하고 있다. 천자흡입 생검도 수술 전에 복벽종괴의 감별 진단에 사용 할 수 있으나, 전이성 종양과의 감별에 난점이 많고, 병변이 탈장낭일 경우에는 위험할 수 있다[6]. 본 증례에서는 모두 광범위 절제술을 통 해 진단하였으며, 천자흡입 생검 등은 시행하지 않았다. 양수천자술 후 의 바늘 천자 부위에서 자궁내막종이 발생한 경우도 보고된 바 있으므 로, 천자흡입생검 시에는 수술절제를 계획한 부위 내부에서 시행할 것 이 권장된다[13].

골반강외 자궁내막증 중에서도 샅굴 부위 자궁내막증의 경우 그 빈 도가 극히 드물어 Sun 등[14]은 전체 자궁내막증 중 $0.07 \%$ 에서 발생 하였으며, 이 중 $88.9 \%$ 가 본 병원의 사례와 같이 우측에서 발생하였다 고 보고하였다. 이처럼 샅굴 부위에 발생하는 자궁내막증이 우측에서 


\section{KOREAN JOURNAL OF OBSTETRICS \& GYNECOLOGY}

Seong Eui Lee, et al. Clinicopathologic review of extrapelvic endometriosis

주로 발생하는 이유는 장의 연동운동과 횡격막의 운동으로 인한 복강 내 정수압의 변화로 복막액의 흐름이 시계 방향으로 생성되고 이러한 흐름에 따라 복막액이 우측 복막내 고랑(peritoneal gutter)을 향할 때 중력 때문에 자궁내막 세포가 우측에 더 오래 머무르기 때문으로 여겨 진다. 여기에 이차적으로 구불창자(sigmoid colon)가 상대적으로 좌측 샅굴 부위를 보호하기 때문인 것으로 생각된다[15,16].

자궁경부에 발생하는 자궁내막증의 경우 대부분 무증상이나 성교 후 질출혈이나 정기 부인과 검진 시 자궁경부세포검사 결과 이상으로 발 견되는 경우도 있다. 자궁경부 자궁내막증 환자에서 실시한 자궁경부 세포검사는 그 결과가 정상에서 high-grade squamous intraepithelial lesion (HSIL)까지 다양하여 초기 감별이 어려우므로 자궁경부 펀치생 검 및 자궁경부확대경검사 등 추가검사로 확진되는 경우가 많다[17] 자궁경부의 자궁내막증이 자궁경부세포검사나, 펀치생검 등에서 자궁 경부의 선세포암으로 오인되어 과도한 치료를 시도한 증례 등의 보고 가 있어[18] 자궁경부세포검사에 대한 주의 깊은 해석이 필요할 것으 로 생각되며, 본 연구에서도 자궁경부세포검사에서 atypical glandular cells of undertermined significance (AGUS)를 보였으나 진단적 자궁 경부원추절제술에서는 자궁내막증과 만성 자궁경부염으로 진단된 1예 가 있다.

종괴를 형성한 골반강외 자궁내막증의 치료의 경우 종괴 부위 절제 술이 완치율은 $95 \%$ 이나 재발률은 $4.3 \%$ 로 보고되어 다른 치료법과 비 교해 우선 추천되는 치료법이다. 수술 후 부분 재발의 경우 불완전한 절제로 인한 경우가 대부분으로 수술 시 $1 \mathrm{~cm}$ 이상의 경계를 둔 광범 위 절제술이 추천된다. 특히 반흔 부위나 복벽에 생긴 자궁내막증의 경 우 호르몬 치료에 대한 반응율이 좋지 않은 것으로 알려져 있다 [4,19].

자궁경부 자궁내막증의 경우 증상이 없고, 자궁경부세포검사에 이상 이 없다면 특별한 치료를 필요치 않으나, 부정기 출혈, 성교 후 출혈 등 증상이 있는 경우 환상투열절제(large loop excision of transformational Zone, LEEP)나이나 다른 자궁경부소작술 등의 외과적 치료가 필요로 한다. 치료 후에는 치료 부위의 완전 회복 전에 생리혈로 인한 자궁내 막의 재 착상을 방지하기 위해 4주간 프로게스테론 또는 경부 피임약 을 복용하는 것이 추천된다[20].

결론적으로 생리 주기에 따른 통증이나 종괴를 호소하는 여성에 있 어 추정 진단으로서 자궁내막증을 간과해서는 안되며, 특히 골반부 수 술의 기왕력이 있는 경우 반드시 이를 감별해야 할 것이다. 또한 자궁 외 임신이나 자궁경부 상피 병변이 없는 환자에서 성교 후 질출혈이 있 거나 비정상 자궁경부세포검사 결과가 나올 경우에도 자궁내막증을 감 별 질환의 하나로 염두에 두어야 할 것이다. 골반강외 자궁내막증의 치 료도 골반강내 자궁내막증과 마찬가지로 일차적으로 가능한 광범위 국 소 절제술을 시행하는 것이 치료 및 재발 방지에 도움이 된다.

\section{Acknowledgments}

이 논문은 부산대학교 자유과제학술비(2년)에 의하여 연구되었음.

\section{References}

1. Fernández Vozmediano JM, Armario Hita JC, Cuevas Santos J. Cutaneous endometriosis. Int J Dermatol 2010;49:1410-2.

2. Sataloff DM, La Vorgna KA, McFarland MM. Extrapelvic endometriosis presenting as a hernia: clinical reports and review of the literature. Surgery 1989;105:109-12.

3. Brenner C, Wohlgemuth S. Scar endometriosis. Surg Gynecol Obstet 1990;170:538-40.

4. Blanco RG, Parithivel VS, Shah AK, Gumbs MA, Schein $M$, Gerst PH. Abdominal wall endometriomas. Am J Surg 2003;185:596-8.

5. Healy JT, Wikinson NW, Sawyer M. Abdominal wall endometrioma in a laparoscopic trocar tract: a case report. Am Surg 1995;61:962-3.

6. Kaunitz A, Di Sant'Agnese PA. Needle tract endometriosis: an unusual complication of amniocentesis. Obstet Gynecol 1979;54:753-5.

7. Griffin JB, Betsill WL Jr. Subcutaneous endometriosis diagnosed by fine needle aspiration cytology. Acta Cytol 1985;29:584-8.

8. Liang CC, Tsai CC, Chen TC, Soong YK. Management of perineal endometriosis. Int J Gynaecol Obstet 1996;53:261-5.

9. Balleyguier C, Chapron C, Chopin N, Hélénon O, Menu Y. Abdominal wall and surgical scar endometriosis: results of magnetic resonance imaging. Gynecol Obstet Invest 2003;55:220-4.

10. Dragoumis K, Mikos T, Zafrakas M, Assimakopoulos E, Stamatopoulos P, Bontis J. Endometriotic uterocutaneous fistula after cesarean section: a case report. Gynecol Obstet Invest 2004;57:90-2.

11. Kang SI, Kim JW, Kim SK, Chung CW, Kwon SW, Ahn DH, et al. Ectopic endometriosis of the extra-pelvic cavity. J Korean Surg Soc 2008;74:443-7.

12. Seydel AS, Sickel JZ, Warner ED, Sax HC. Extrapelvic endometriosis: diagnosis and treatment. Am J Surg 1996;171:239.

13. Koger KE, Shatney CH, Hodge K, McClenathan JH. Surgical scar endometrioma. Surg Gynecol Obstet 1993;177:243-6.

14. Sun ZJ, Zhu L, Lang JH. A rare extrapelvic endometriosis: inguinal endometriosis. J Reprod Med 2010;55:62-6.

15. Candiani GB, Vercellini P, Fedele L, Vendola N, Carinelli S, Scaglione V. Inguinal endometriosis: pathogenetic and clinical implications. Obstet Gynecol 1991;78:191-4.

16. Mashfiqul MA, Tan YM, Chintana CW. Endometriosis of the inguinal canal mimicking a hernia. Singapore Med J 2007;48:e157-9.

17. Selo-Ojeme D, Freeman-Wang T, Khan NH. Post-coital bleed- 


\section{KOREAN JOURNAL OF OBSTETRICS \& GYNECOLOGY}

KJOG Vol. 55, No. 2, 2012

ing: a rare and unusual presentation of cervical endometriosis. Arch Gynecol Obstet 2006;273:370-3.

18. Baker PM, Clement PB, Bell DA, Young RH. Superficial endometriosis of the uterine cervix: a report of 20 cases of a process that may be confused with endocervical glandular dysplasia or adenocarcinoma in situ. Int J Gynecol Pathol 1999;18:198-205.
19. Bektaş H, Bilsel Y, Sari YS, Ersöz F, Koç O, Deniz M, et al. Abdominal wall endometrioma; a 10-year experience and brief review of the literature. J Surg Res 2010;164:e77-81.

20. Wong FW, Lim CE, Karia S, Santos L. Cervical endometriosis: case series and review of literature. J Obstet Gynaecol Res 2010;36:916-9.

\section{골반강외 자궁내막증에 대한 임상적 고찰}

\section{부산대학교 의학전문대학원 산부인과학교실}

이성의, 정주은, 주종길, 이규섭

목적

골반강외 자궁내막증으로 진단 받은 환자를 대상으로 조사하여 발생 빈도 및 임상 양상에 관해 알아보기로 하였다.

\section{연구방법}

1998년 1월부터 2009년 12월까지 부산대학교병원 산부인과에서 수술받은 환자 중 골반강외 자궁 자궁내막으로 진단된 30명의 환자를 대상으로 하여 이들 환자의 의무기록을 바탕으로 하여 후향적으로 분석하였다.

\section{결과}

11년간 부산대병원 산부인과에서 골반강외 자궁내막증으로 진단받은 환자는 30명이었으며, 이들의 평균 나이는 38세였다. 주 호소 증상 으로는 생리 주기와 연관된 주기적 압통성 종괴를 호소하는 경우가 21예(67\%), 비주기성 압통성 종괴가 9예(33\%)였다. 골반강외 자궁내 막증의 발생 부위별로 살펴보면 이전 제왕절개술이나 복강경 반흔에 발생한 경우가 15예로 가장 많았고, 자궁경부에 발생한 경우가 10예, 질식분만 후 회음절개 부위의 발생이 3 예, 그 외 서혜부와 질에서 발생한 경우가 각각 1 예에서 관찰되었다.

\section{결론}

생리 주기에 따른 통증이나 종괴를 호소하는 여성에 있어 추정 진단으로서 자궁내막증을 간과해서는 안되며, 특히 골반부 수술의 기왕력 이 있는 경우 반드시 이를 감별해야 할 것이다. 골반강외 자궁내막증의 치료도 골반강내 자궁내막증과 마찬가지로 일차적으로 가능한 광 범위 국소절제술을 시행하는 것이 치료 및 재발 방지에 도움이 된다.

중심단어: 골반강외 자궁내막증, 증상, 진단, 치료 